\title{
Hubungan antara Konsep Diri dengan Depresi pada Transgender: Kajian Literatur
}

\author{
Salsabila Nur Istigfari ${ }^{*}$, Elis Hartati ${ }^{1}$ \\ ${ }^{1}$ Departemen Ilmu Keperawatan Fakultas Kedokteran Universitas Diponegoro, Semarang, \\ Indonesia \\ salsabilanuristigfari@gmail.com
}

\begin{abstract}
Introduction: Transgenders have a high risk of depression caused by self-concept. the complex aspect of self-concept has led to different results among researchers in examining the relationship between self-concept and depression experienced by transgender. The purpose of this study was to strengthen evidence on the relationship between self-concept and depression in transgender.

Method: This study uses a literature review method. Articles searched through Google Scholar, Cambridge, Clinical Key, NCBI, MDPI, and Science Direct. Articles were selected based on several criteria including: research with a minimum sample of 15 transgender, publication year 2011-2020, written in Indonesian or English, and full text articles. Quality assessment as a method to assess the relevance of the journals.

Results: Eleven articles were selected based on the sample criteria, but only 7 articles were relevant to be reviewed. The results of the synthesis show that there is a relationship between self-concept and depression in transgender people. The level of depression in transgender is influenced by several factors, including: lack of social support, low self-esteem, body image dissatisfaction, lack of coping skills, social and emotional loneliness, and low sexual satisfaction.

Conclusion: There is a significant relationship between self-concept and depression in transgender people, but there is no strong evidence that proves the influence of organizational involvement on selfconcept in transgender.
\end{abstract}

Keywords: Depression, Self-Concept, Transgender.

\begin{abstract}
Abstrak
Pendahuluan: Transgender memiliki risiko depresi yang tinggi disebabkan oleh konsep diri. Aspek kompleks konsep diri menimbulkan berbagai hasil penelitian yang berbeda dalam mengkaji hubungan antara konsep diri dengan depresi yang dialami oleh para transgender. Tujuan penelitian ini adalah untuk memperkuat bukti tentang hubungan antara konsep diri dengan depresi pada transgender.

Metode: Penelitian ini menggunakan metode kajian literatur. Artikel dicari melalui Google Scholar, Cambridge, Clinical Key, NCBI, MDPI, dan Science Direct. Artikel dipilih berdasarkan beberapa kriteria diantaranya: penelitian dengan minimal sampel sebanyak 15 transgender, tahun publikasi 20112020, ditulis dalam bahasa Indonesia atau Inggris, menggunakan desain penelitian kuantitatif atau crosssectional, dan artikel full text. Quality assessment untuk menilai tingkat relevansi jurnal yang diperoleh. Hasil: Sebanyak 7 artikel yang relevan untuk dikaji. Hasil sintesis menunjukkan adanya hubungan antara konsep diri dengan depresi pada transgender. Tingkat depresi pada transgender dipengaruhi oleh beberapa faktor, diantaranya: kurangnya dukungan sosial, rendahnya harga diri, ketidakpuasan citra tubuh, kurangnya kemampuan koping, kesepian sosial dan emosional, dan rendahnya kepuasan seksual. Kesimpulan: Terdapat hubungan signifikan antara konsep diri dan depresi pada transgender, namun belum ada bukti kuat yang membuktikan adanya pengaruh keterlibatan organisasi terhadap konsep diri pada transgender. Disarankan bagi peneliti selanjutnya untuk melakukan penelitian lebih lanjut melalui pengambilan sampel pada kelompok transgender dalam komunitas.
\end{abstract}

Kata Kunci: Depresi, Konsep Diri, Transgender. 


\section{PENDAHULUAN}

Depresi diidentifikasi sebagai salah satu dari empat penyakit utama dalam dunia, yang juga dianggap sebagai penyebab kecacatan yang paling umum dari penyakit (Sarokhani et al., 2013). Depresi ditandai oleh adanya suasana hati yang sedih, putus asa, mudah tersinggung, disertai dengan perubahan somatik dan kognitif yang secara signifikan mempengaruhi kapasitas fungsi individu (American Psychiatric Association, 2013). Riset Kesehatan Dasar (Riskesdas) tahun 2018 menyebutkan prevalensi penderita depresi pada penduduk umur $\geq 15$ cukup tinggi, yakni mencapai $6.1 \%$ penduduk Indonesia. Berdasarkan data tersebut, melalui wawancara dengan Mini International Neuropsychiatric Interview (MINI), dinyatakan bahwa sebanyak 91\% penderita tidak melakukan program pengobatan (Kementerian Kesehatan Republik Indonesia, 2018).

Salah satu populasi yang memiliki risiko tinggi terhadap depresi adalah transgender. Tingkat prevalensi depresi pada transgender berkisar antara 48\% hingga $\quad 62 \% \quad$ (Tantirattanakulchai, Hounnaklang, \& Kanchanakhan, 2019). Transgender merupakan sebutan bagi seseorang dengan abnormalitas seksual dan penyimpangan identitas gender. Terdapat gangguan pada kalangan transgender baik secara psikologis, sosial, dan budaya dalam hubungan dengan lingkungan di sekitarnya. Hal ini dikarenakan transgender berpotensi untuk mendapatkan kecaman, tindak kekerasan dan diskriminasi atas pandangan mengenai tubuh, seksualitas, dan peran seksual dalam kehidupan sehari-hari (Praptoraharjo \& Navendorff, 2015).
Penyimpangan arah tujuan seksual pada transgender memberikan dampak pula terhadap perubahan konsep diri seorang transgender. Ketidakpuasan seorang transgender atas bentuk fisiknya, memiliki pengaruh besar dalam proses pembentukan konsep dirinya. Identitas gender merupakan masalah mendasar pula bagi seorang transgender yang mengakibatkan terjadinya konflik psikologis berkaitan dengan keinginan yang berlawanan dengan keadaan fisiknya (Arfanda \& Anwar, 2015). Memiliki konsep diri positif dan pemahaman yang lebih besar tentang peran transgender dalam kehidupan seseorang, dikaitkan dengan penurunan kemungkinan gejala depresi (Jefferson, Neilands, \& Sevelius, 2013). Dukungan sosial, identitas, serta keterlibatan dalam komunitas berpengaruh pula terhadap proses pembentukan konsep diri yang baik, sehingga dapat mencegah timbulnya gejala depresi pada transgender (Rotondi et al., 2011).

Hasil penelitian membuktikan adanya berbagai faktor konsep diri sebagai penyebab timbulnya depresi pada transgender. Adanya aspek konsep diri secara personal maupun sosial yang cukup kompleks pada transgender mengakibatkan timbulnya berbagai hasil yang berbeda diantara para peneliti dalam mengkaji hubungan antara konsep diri dengan depresi yang dialami oleh para transgender. Guna menegakkan dan memperkuat bukti terkait hubungan antara berbagai aspek konsep diri transgender dengan fenomena depresi yang dialami, maka penulis merumuskan desain penelitian literature review terkait hubungan antara konsep diri dengan depresi pada transgender. 
METODE

Penelitian ini dilakukan menggunakan metode kajian literatur atau kepustakaan. Metode pencarian literatur dilakukan melalui penelusuran artikel dengan kata kunci, dalam Bahasa Inggris "self-concept", "depression", "transgender", dan "gender congruence". Kata kunci dalam Bahasa Indonesia meliputi "konsep diri", "depresi", "transgender", dan "kongruensi gender". Sumber literatur diperoleh dari beberapa portal diantaranya: Google Scholar, Cambridge, Clinical Key, NCBI, MDPI, dan Science Direct, dengan rentang waktu publikasi tahun 2011-2020.

Pencarian literatur dilakukan melalui seleksi berdasarkan kriteria sampel dan quality assessment. Penetapan kriteria sampel ditujukan untuk menginklusi dan mengeksklusi artikel jurnal yang didapatkan berdasarkan kesesuaian dengan topik, aggregate, serta desain penelitian yang digunakan. Artikel dipilih berdasarkan kriteria inklusi diantaranya: 1) Artikel penelitian dengan minimal jumlah sampel sebanyak 15 transgender; 2) Tahun publikasi 2011-2020; 3) Berbahasa Indonesia atau Inggris; 4) Artikel dalam bentuk full text.

Quality assesment selanjutkan dilakukan sebagai penilaian kelayakan artikel jurnal yang didasarkan pada kemampuan instrumen yang digunakan dalam artikel jurnal untuk mengukur konsep diri dan depresi, terkait beberapa aspek diantaranya:

$\begin{array}{ll}\text { KD1 } & \text { Aspek Identitas Diri } \\ \text { KD2 } & \text { Aspek Citra Tubuh } \\ \text { KD3 } & \text { : Aspek Peran } \\ \text { KD4 } & \text { : Aspek Harga Diri } \\ \text { KD5 } & \text { : Aspek Ideal Diri }\end{array}$

D1 : Gejala Fisik Depresi

D2 : Gejala Psikologis Depresi

Seluruh artikel jurnal yang diperoleh, dilakukan penilaian berdasarkan masing-masing aspek penilaian di atas melalui indikator skor sebagai berikut:

1 : aspek terukur dalam instrumen

0 : aspek tidak terukur dalam instrumen

Hasil akhir quality assessment didasarkan pada perolehan total skor dengan rentang penilaian (QA score $=0-7$ ). Semakin tinggi skor yang diperoleh mengindikasikan semakin kuat relevansi jurnal dengan kedua variabel yang akan diteliti. Artikel jurnal dengan tingkat relevansi rendah (QA score $<4)$ dieksklusi.

\section{HASIL}

Gambar 1 menunjukkan hasil pemilihan artikel berdasarkan penelusuran artikel. Sebanyak 50 artikel telah ditemukan dan sebelas artikel terpilih berdasarkan kriteria sampel, tetapi hanya tujuh artikel yang relevan untuk dikaji. Hasil pengambilan sampel tersebut diidentifikasikan pada Tabel 1. Penilaian relevansi jurnal dengan quality assessment dilakukan melalui proses scoring terhadap sebelas jurnal yang telah memenuhi kriteria inklusi. Hasil penilaian quality assessment dapat dilihat pada Tabel 2.

Berdasarkan hasil penilaian quality assessment, diperoleh tujuh artikel terinklusi yang dinilai layak dan relevan dengan penelitian. Selanjutnya, analisa data dilakukan dengan melakukan proses review dan sintesa terhadap artikel tersebut. Tabel 3 menunjukkan sintesis ide pokok dari artikel terkait konsep diri dan depresi pada transgender. 
Gambar 1. Skema Reduksi Referensi

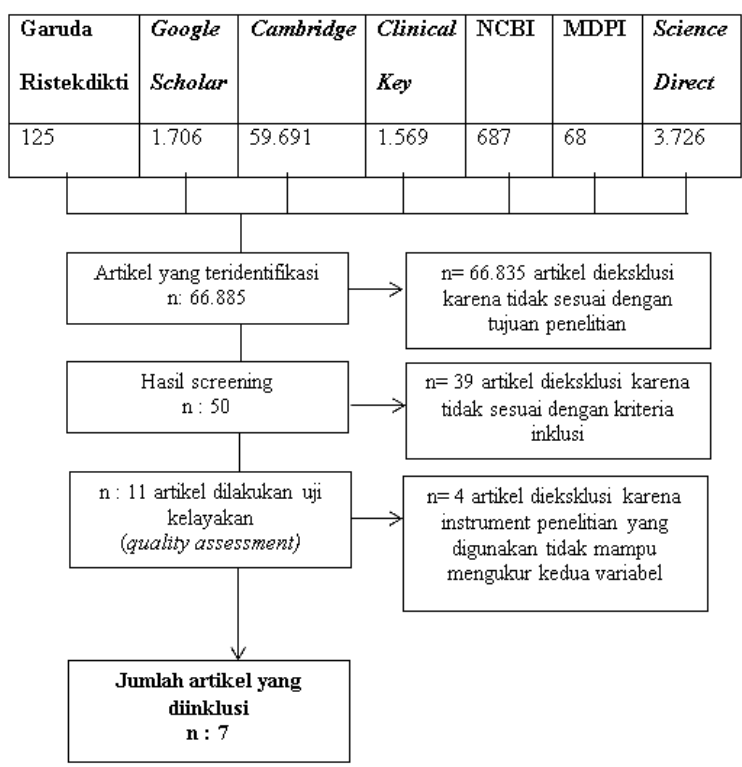

Hasil sintesis membuktikan adanya hubungan antara komponen pembentukan konsep diri dengan fenomena depresi yang terjadi pada transgender. Aspek-aspek terkait konsep diri pada transgender berkaitan erat dengan respon psikologis serta koping seorang transgender, sehingga memiliki hubungan yang signifikan dengan depresi. Transgender sebagai individu yang memiliki penyimpangan orientasi seksual, mengalami gejala depresi akibat adanya pertentangan dengan nilai sosial dan budaya yang dianut oleh masyarakat (Pieter \& Lubis, 2010).

Faktor yang menjadi pemicu terjadinya depresi pada transgender diantaranya ideal diri secara personal terkait penampilan fisik, serta ideal diri secara interpersonal yang meliputi dukungan sosial, fungsi peran, serta harga diri. Pemenuhan aspek ideal diri pada transgender tersebut dikorelasikan dengan kemungkinan penurunan tingkat depresi pada transgender.

Tabel 1. Hasil Seleksi Literatur berdasarkan Kriteria Sampel

\begin{tabular}{|c|c|c|c|c|c|}
\hline No. & Judul Artikel & Nama Jurnal & Tahun & $\begin{array}{l}\text { Sampel } \\
\text { (n) }\end{array}$ & $\begin{array}{l}\text { Desain } \\
\text { Penelitian }\end{array}$ \\
\hline 1. & $\begin{array}{l}\text { Depression in male-to-female transgender } \\
\text { ontarians: Results from the trans PULSE } \\
\text { project }\end{array}$ & $\begin{array}{l}\text { Canadian Journal of } \\
\text { Community Mental Health }\end{array}$ & 2011 & 433 & Kuantitatif \\
\hline 2. & $\begin{array}{l}\text { Anxiety and Depression in transgender } \\
\text { individuals: The roles of transition status, } \\
\text { loss, social support, and coping. }\end{array}$ & $\begin{array}{l}\text { Journal of Consulting and } \\
\text { Clinical Psychology }\end{array}$ & 2013 & 351 & Kuantitatif \\
\hline 3. & $\begin{array}{l}\text { Exploring the Link between Internalized } \\
\text { Stigma and Self-Concept Clarity among } \\
\text { Filipino Transgenders }\end{array}$ & $\begin{array}{l}\text { North American Journal of } \\
\text { Psychology }\end{array}$ & 2016 & 114 & Kuantitatif \\
\hline 4. & $\begin{array}{l}\text { Beyond depression and suicide: The mental } \\
\text { health of transgender college students }\end{array}$ & Social Sciences & 2017 & 1143 & Kuantitatif \\
\hline 5. & $\begin{array}{l}\text { Hormone therapy, gender affirmation } \\
\text { surgery, and their association with recent } \\
\text { suicidal ideation and depression symptoms } \\
\text { in transgender veterans }\end{array}$ & Psychological Medicine & 2018 & 206 & $\begin{array}{l}\text { Cross } \\
\text { Sectional }\end{array}$ \\
\hline 6. & $\begin{array}{l}\text { Transphobia-based violence, depression, } \\
\text { and anxiety in transgender women: The role } \\
\text { of body satisfaction }\end{array}$ & $\begin{array}{l}\text { Journal of Interpersonal } \\
\text { Violence }\end{array}$ & 2018 & 233 & Kuantitatif \\
\hline 7. & $\begin{array}{l}\text { Levels of depression in transgender people } \\
\text { and its predictors: Results of a large } \\
\text { matched control study with transgender } \\
\text { people accessing clinical services }\end{array}$ & $\begin{array}{l}\text { Journal of Affective } \\
\text { Disorders }\end{array}$ & 2018 & 913 & Kuantitatif \\
\hline 8. & $\begin{array}{l}\text { Minority stress factors associated with } \\
\text { depression and anxiety among transgender } \\
\text { and gender-nonconforming youth }\end{array}$ & $\begin{array}{l}\text { Journal of Adolescent } \\
\text { Health }\end{array}$ & 2019 & 109 & Kuantitatif \\
\hline
\end{tabular}


Tabel 1. Hasil Seleksi Literatur berdasarkan Kriteria Sampel (lanjutan)

\begin{tabular}{|c|c|c|c|c|c|}
\hline No. & Judul Artikel & Nama Jurnal & Tahun & $\begin{array}{l}\text { Sampel } \\
\text { (n) }\end{array}$ & $\begin{array}{c}\text { Desan } \\
\text { Penelitian }\end{array}$ \\
\hline 9. & $\begin{array}{l}\text { A cross-sectional research on factors } \\
\text { associated with depression among } \\
\text { transgender women in Bangkok, Thailand }\end{array}$ & $\begin{array}{l}\text { International Journal of } \\
\text { Innovative Technology and } \\
\text { Exploring Engineering }\end{array}$ & 2019 & 108 & Kuantitatif \\
\hline 10. & $\begin{array}{l}\text { Mental health and proximal stressors in } \\
\text { transgender men and women }\end{array}$ & $\begin{array}{l}\text { Journal of Clinical } \\
\text { Medicine }\end{array}$ & 2019 & 120 & Kuantitatif \\
\hline 11. & $\begin{array}{l}\text { Perceived parental acceptance, transgender } \\
\text { congruence, and psychological well-being of } \\
\text { Filipino Transgender individuals }\end{array}$ & $\begin{array}{l}\text { North Aerican Journal of } \\
\text { Psychology }\end{array}$ & 2020 & 108 & Kuantitatif \\
\hline
\end{tabular}

Tabel 2. Hasil Penilaian Quality Assessment

\begin{tabular}{|c|c|c|c|c|c|c|c|c|c|c|}
\hline \multirow{3}{*}{ Judul Artikel } & \multirow{3}{*}{$\begin{array}{l}\text { Instrumen yang } \\
\text { digunakan }\end{array}$} & \multicolumn{7}{|c|}{ Quality Assessment } & \multirow{3}{*}{$\begin{array}{l}\text { QA } \\
\text { Score }\end{array}$} & \multirow{3}{*}{$\begin{array}{c}\text { Kategori } \\
\text { Jurnal }\end{array}$} \\
\hline & & \multicolumn{5}{|c|}{ Konsep Diri } & \multicolumn{2}{|c|}{ Depresi } & & \\
\hline & & KD1 & KD2 & KD3 & KD4 & KD5 & D1 & $\mathrm{D} 2$ & & \\
\hline $\begin{array}{l}\text { Depression in } \\
\text { male-to-female } \\
\text { transgender } \\
\text { ontarians: Results } \\
\text { from the trans } \\
\text { PULSE project } \\
\text { (Rotondi et al., } \\
\text { 2011) }\end{array}$ & $\begin{array}{c}\text { Center for } \\
\text { Epidemiological } \\
\text { Studies-Depression } \\
\text { Scale (CES-D), } \\
\text { Multidimensional Sexual } \\
\text { Self-Concept } \\
\text { Questionnaire }\end{array}$ & 1 & 1 & 1 & 1 & 1 & 1 & 1 & 7 & $\begin{array}{l}\text { Relevansi } \\
\text { Tinggi } \\
\text { (included) }\end{array}$ \\
\hline $\begin{array}{l}\text { Anxiety and } \\
\text { depression in } \\
\text { transgender } \\
\text { individuals: The } \\
\text { roles of transition } \\
\text { status, loss, social } \\
\text { support, and } \\
\text { coping } \\
\text { (Budge, Andelson, } \\
\text { \& Howard, 2013) }\end{array}$ & $\begin{array}{l}\text { Multidimensional Scale } \\
\text { of Social Support } \\
\text { (MSPSS), Transgender } \\
\text { Perception of Loss } \\
\text { Scale, Center for } \\
\text { Epidemiological } \\
\text { Studies-Depression } \\
\text { Scale (CES-D), Burns } \\
\text { Anxiety Inventory }\end{array}$ & 0 & 0 & 0 & 1 & 0 & 1 & 1 & 3 & $\begin{array}{l}\text { Relevansi } \\
\text { Rendah } \\
\text { (excluded) }\end{array}$ \\
\hline $\begin{array}{l}\text { Exploring the link } \\
\text { between } \\
\text { internalized stigma } \\
\text { and self-concept } \\
\text { clarity among } \\
\text { Filipino } \\
\text { Transgenders } \\
\text { (Reyes et al., 2016) }\end{array}$ & $\begin{array}{c}\text { Internalized } \\
\text { Transphobia Scale, Self- } \\
\text { Stigma Scale, Self- } \\
\text { Concept Clarity Scale. }\end{array}$ & 1 & 0 & 1 & 1 & 1 & 0 & 1 & 5 & $\begin{array}{l}\text { Relevansi } \\
\text { Sedang } \\
\text { (included) }\end{array}$ \\
\hline $\begin{array}{l}\text { Beyond depression } \\
\text { and suicide: The } \\
\text { mental health of } \\
\text { transgender college } \\
\text { students } \\
\text { (Oswald \& } \\
\text { Lederer, 2017) }\end{array}$ & ACHA-NCHA II & 1 & 0 & 0 & 0 & 0 & 1 & 1 & 3 & $\begin{array}{l}\text { Relevansi } \\
\text { Rendah } \\
\text { (excluded) }\end{array}$ \\
\hline $\begin{array}{l}\text { Hormone therapy, } \\
\text { gender affirmation } \\
\text { surgery, and their } \\
\text { association with } \\
\text { recent suicidal } \\
\text { ideation and } \\
\text { depression } \\
\text { symptoms in } \\
\text { transgender } \\
\text { veterans } \\
\text { (Tucker et al., } \\
\text { 2018) }\end{array}$ & $\begin{array}{c}\text { Suicidal Behaviors } \\
\text { Questionnaire - Revised } \\
\text { (SBQ-R), Patient Health } \\
\text { Questionnaire-9 (PHQ- } \\
\text { 9) }\end{array}$ & 1 & 1 & 0 & 0 & 0 & 1 & 1 & 4 & $\begin{array}{l}\text { Relevansi } \\
\text { Sedang } \\
\text { (included) }\end{array}$ \\
\hline
\end{tabular}


Tabel 2. Hasil Penilaian Quality Assessment (lanjutan)

\begin{tabular}{|c|c|c|c|c|c|c|c|c|c|c|}
\hline \multirow{3}{*}{ Judul Artikel } & \multirow{3}{*}{$\begin{array}{c}\text { Instrumen yang } \\
\text { digunakan }\end{array}$} & \multicolumn{7}{|c|}{ Quality Assessment } & \multirow{3}{*}{$\begin{array}{l}\text { QA } \\
\text { Score }\end{array}$} & \multirow{3}{*}{$\begin{array}{c}\text { Kategori } \\
\text { Jurnal }\end{array}$} \\
\hline & & \multicolumn{7}{|c|}{ Kondep Diri } & & \\
\hline & & KD1 & KD2 & KD3 & KD4 & KD5 & D1 & D2 & & \\
\hline $\begin{array}{l}\text { Transphobia-based } \\
\text { violence, depression, } \\
\text { and anxiety in } \\
\text { transgender women: } \\
\text { The role of body } \\
\text { satisfaction } \\
\text { (Klemmer et al., } \\
2018 \text { ) }\end{array}$ & $\begin{array}{l}\text { Transphobia- } \\
\text { Based Violence, } \\
\text { Degree of Body } \\
\text { Satisfaction, and } \\
\text { Mental Health } \\
\text { (Likert Scale } \\
\text { Questions) }\end{array}$ & 1 & 1 & 1 & 0 & 1 & 0 & 1 & 5 & $\begin{array}{c}\text { Relevansi } \\
\text { Sedang } \\
\text { (included) }\end{array}$ \\
\hline $\begin{array}{l}\text { Levels of depression } \\
\text { in transgender } \\
\text { people and its } \\
\text { predictors: Results } \\
\text { of a large matched } \\
\text { control study with } \\
\text { transgender people } \\
\text { accessing clinical } \\
\text { services } \\
\text { (Witcomb et. al., } \\
\text { 2018) }\end{array}$ & $\begin{array}{l}\text { Hospital Anxiety } \\
\text { and Depression } \\
\text { Scale (HADS), } \\
\text { Rosenberg Self- } \\
\text { Esteem Scale } \\
\text { (RSE), } \\
\text { Experiences of } \\
\text { Transgender } \\
\text { Phobia Scale, } \\
\text { Multidimensional } \\
\text { Scale of } \\
\text { Perceived Social } \\
\text { Support } \\
\text { (MSPSS) }\end{array}$ & 1 & 1 & 1 & 1 & 1 & 1 & 1 & 7 & $\begin{array}{l}\text { Relevansi } \\
\text { Tinggi } \\
\text { (included) }\end{array}$ \\
\hline $\begin{array}{l}\text { Minority stress } \\
\text { factors associated } \\
\text { with depression and } \\
\text { anxiety among } \\
\text { transgender and } \\
\text { gender- } \\
\text { nonconforming } \\
\text { youth } \\
\text { (Chodzen et. al., } \\
\text { 2019) }\end{array}$ & $\begin{array}{c}\text { Transgender } \\
\text { Congruence } \\
\text { Scale (TCS), } \\
\text { Gender Minority } \\
\text { Stress and } \\
\text { Resilience }\end{array}$ & 1 & 0 & 0 & 1 & 1 & 1 & 1 & 5 & $\begin{array}{l}\text { Relevansi } \\
\text { Sedang } \\
\text { (included) }\end{array}$ \\
\hline $\begin{array}{l}\text { A cross-sectional } \\
\text { research on factors } \\
\text { associated with } \\
\text { depression among } \\
\text { transgender women } \\
\text { in Bangkok, } \\
\text { Thailand } \\
\text { (Tantirattanakulchai, } \\
\text { Hounnaklang, \& } \\
\text { Kanchanakhan, } \\
\text { 2019) }\end{array}$ & $\begin{array}{c}\text { Center for } \\
\text { Epidemiological } \\
\text { Studies- } \\
\text { Depression Scale } \\
\text { (CES-D) }\end{array}$ & 0 & 1 & 0 & 0 & 0 & 1 & 1 & 3 & $\begin{array}{c}\text { Relevansi } \\
\text { Rendah } \\
\text { (included) }\end{array}$ \\
\hline $\begin{array}{l}\text { Mental health and } \\
\text { proximal stressors in } \\
\text { transgender men and } \\
\text { women } \\
\text { (Fernández-Rouco et } \\
\text { al., 2019) }\end{array}$ & $\begin{array}{c}\text { Tennessee Self- } \\
\text { Concept Scale } \\
2^{\text {nd }} \text { Edition } \\
\text { (TSCS: 2), The } \\
\text { Body Image } \\
\text { Scale, Self- } \\
\text { Concept } \\
\text { Questionnaire } \\
\text { (MSSCQ), } \\
\text { Checklis of } \\
\text { Derogatis (SCL- } \\
\text { 90-R) }\end{array}$ & 1 & 1 & 1 & 1 & 1 & 0 & 1 & 6 & $\begin{array}{c}\text { Relevansi } \\
\text { Sedang } \\
\text { (included) }\end{array}$ \\
\hline
\end{tabular}


Tabel 2. Hasil Penilaian Quality Assessment (lanjutan)

\begin{tabular}{|c|c|c|c|c|c|c|c|c|c|c|}
\hline \multirow{3}{*}{ Judul Artikel } & \multirow{3}{*}{$\begin{array}{c}\text { Instrumen yang } \\
\text { digunakan }\end{array}$} & \multicolumn{7}{|c|}{ Quality Assessment } & \multirow{3}{*}{$\begin{array}{l}\text { QA } \\
\text { Score }\end{array}$} & \multirow{3}{*}{$\begin{array}{c}\text { Kategori } \\
\text { Jurnal }\end{array}$} \\
\hline & & \multicolumn{7}{|c|}{ Kondep Diri } & & \\
\hline & & KD1 & KD2 & KD3 & KD4 & KD5 & D1 & D2 & & \\
\hline $\begin{array}{l}\text { Perceived parental } \\
\text { acceptance, } \\
\text { transgender } \\
\text { congruence, and } \\
\text { psychological well- } \\
\text { being of Filipino } \\
\text { transgender } \\
\text { individuals } \\
\text { (Reyes et al., 2020) }\end{array}$ & $\begin{array}{c}\text { Transgender } \\
\text { Congruence } \\
\text { Scale (TCS), Ryff } \\
\text { Scale of } \\
\text { Psychological } \\
\text { Well Being } \\
\text { (RPWB) }\end{array}$ & 1 & 1 & 0 & 0 & 0 & 0 & 1 & 3 & $\begin{array}{l}\text { Relevansi } \\
\text { Rendah } \\
\text { (excluded) }\end{array}$ \\
\hline
\end{tabular}

Tabel 3. Matriks Sintesis Ide Pokok

\begin{tabular}{|c|c|c|c|}
\hline \multirow[b]{2}{*}{ Judul Artikel } & \multicolumn{3}{|c|}{ Ide Pokok } \\
\hline & $\begin{array}{c}\text { Aspek Konsep Diri pada } \\
\text { Transgender }\end{array}$ & $\begin{array}{c}\text { Tingkat Depresi pada } \\
\text { Transgender }\end{array}$ & $\begin{array}{l}\text { Hubungan Konsep diri dan } \\
\text { Depresi pada Transgender }\end{array}$ \\
\hline $\begin{array}{l}\text { Depression in male- } \\
\text { to-female } \\
\text { transgender } \\
\text { ontarians: Results } \\
\text { from the trans } \\
\text { PULSE project } \\
\text { (Rotondi et al., } \\
2011 \text { ) }\end{array}$ & $\begin{array}{l}\text { Dukungan identitas, dan } \\
\text { citra tubuh menjadi } \\
\text { faktor pembentuk } \\
\text { konsep diri yang kuat } \\
\text { pada transgender. }\end{array}$ & $\begin{array}{l}\text { Peningkatan dukungan } \\
\text { sosial dikaitkan } \\
\text { dengan berkurangnya } \\
\text { kemungkinan gejala } \\
\text { depresi. }\end{array}$ & $\begin{array}{l}\text { Transgender yang mengalami } \\
\text { tingkat dukungan identitas serta } \\
\text { citra tubuh yang tinggi secara } \\
\text { signifikan lebih kecil } \\
\text { kemungkinannya untuk } \\
\text { menunjukkan gejala depresi. }\end{array}$ \\
\hline $\begin{array}{l}\text { Exploring the link } \\
\text { between internalized } \\
\text { stigma and self- } \\
\text { concept clarity } \\
\text { among Filipino } \\
\text { Transgenders } \\
\text { (Reyes et al., 2016) }\end{array}$ & $\begin{array}{l}\text { Skala transphobia, } \\
\text { stigma diri, dan } \\
\text { kejelasan konsep diri } \\
\text { membuktikan stigma } \\
\text { internal berhubungan } \\
\text { dengan kejelasan } \\
\text { konsep diri (stabilitas } \\
\text { dan konsistensi konsep } \\
\text { diri). }\end{array}$ & $\begin{array}{l}\text { Faktor pemicu } \\
\text { depresi pada } \\
\text { transgender yakni } \\
\text { adanya stigma } \\
\text { internal yang relatif } \\
\text { rendah }\end{array}$ & $\begin{array}{l}\text { Transgender dengan stigma diri } \\
\text { rendah memiliki harga diri yang } \\
\text { lebih rendah, peningkatan } \\
\text { pengaruh emosional negatif, } \\
\text { kurang kepercayaan sosial, } \\
\text { tingkat kecemasan yang lebih } \\
\text { besar dan berada pada risiko } \\
\text { depresi yang lebih tinggi. }\end{array}$ \\
\hline $\begin{array}{l}\text { Hormone therapy, } \\
\text { gender affirmation } \\
\text { surgery, and their } \\
\text { association with } \\
\text { recent suicidal } \\
\text { ideation and } \\
\text { depression } \\
\text { symptoms in } \\
\text { transgender } \\
\text { veterans. } \\
\text { (Tucker et al., 2018) }\end{array}$ & $\begin{array}{l}\text { Pembedahan kelamin } \\
\text { dan terapi hormon, } \\
\text { melalui Transition- } \\
\text { related medical } \\
\text { interventions (TRMI), } \\
\text { secara signifikan dapat } \\
\text { meningkatkan konsep } \\
\text { diri transgender terkait } \\
\text { aspek citra tubuh, } \\
\text { identitas, dan ideal diri. }\end{array}$ & $\begin{array}{l}\text { TRMI dalam } 2 \text { minggu } \\
\text { terakhir memberikan } \\
\text { efek tidak langsung } \\
\text { terhadap gejala depresi } \\
\text { yang dialami. }\end{array}$ & $\begin{array}{l}\text { Transition-related medical } \\
\text { interventions (TRMI) berupa } \\
\text { pemberian hormon dan } \\
\text { pembedahan kelamin } \\
\text { memberikan efek perlindungan } \\
\text { terhadap tingkat gejala depresi } \\
\text { dan risiko bunuh diri pada } \\
\text { transgender. }\end{array}$ \\
\hline $\begin{array}{l}\text { Transphobia-based } \\
\text { violence, depression, } \\
\text { and anxiety in } \\
\text { transgender women: } \\
\text { the role of body } \\
\text { satisfaction } \\
\text { (Klemmer et al., } \\
2018 \text { ) }\end{array}$ & $\begin{array}{l}\text { Penggunaan hormon } \\
\text { seumur hidup memberi } \\
\text { pengaruh terhadap } \\
\text { konsep diri transgender } \\
\text { terkait tingkat kepuasan } \\
\text { tubuh yang lebih tinggi } \\
(\mathrm{b}=0,368, \mathrm{t}=3,29, \mathrm{p}= \\
0,001) .\end{array}$ & $\begin{array}{l}\text { Depresi pada } \\
\text { transgender } \\
\text { dipengaruhi oleh } \\
\text { peristiwa yang tidak } \\
\text { menyenangkan, } \\
\text { seperti halnya dipecat } \\
\text { dari pekerjaan dan } \\
\text { sulitnya memperoleh } \\
\text { pekerjaan }\end{array}$ & $\begin{array}{l}\text { Kekerasan psikis dan } \\
\text { transphobia, serta rendahnya } \\
\text { kepuasan citra tubuh secara } \\
\text { signifikan dikaitkan tingginya } \\
\text { diagnosis depresi yang } \\
\text { dilaporkan. }\end{array}$ \\
\hline
\end{tabular}


Tabel 3. Matriks Sintesis Ide Pokok (lanjutan)

\begin{tabular}{|c|c|c|c|}
\hline \multirow[b]{2}{*}{ Judul Artikel } & \multicolumn{3}{|c|}{ Ide Pokok } \\
\hline & $\begin{array}{c}\text { Aspek Konsep Diri pada } \\
\text { Transgender }\end{array}$ & $\begin{array}{l}\text { Tingkat Depresi pada } \\
\text { Transgender } \\
\end{array}$ & $\begin{array}{c}\text { Hubungan Konsep diri dan } \\
\text { Depresi pada Transgender }\end{array}$ \\
\hline $\begin{array}{l}\text { Levels of } \\
\text { depression in } \\
\text { transgender people } \\
\text { and its predictors: } \\
\text { Results of a large } \\
\text { matched control } \\
\text { study with } \\
\text { transgender people } \\
\text { accessing clinical } \\
\text { services } \\
\text { (Witcomb et al., } \\
\text { 2018) }\end{array}$ & $\begin{array}{l}\text { Pembentukan konsep diri } \\
\text { pada transgender } \\
\text { dipengaruhi oleh tingkat } \\
\text { harga diri pada } \\
\text { transgender, terbukti } \\
\text { melalui pengukuran } \\
\text { tingkat konsep diri sosial } \\
\text { pada transgender. }\end{array}$ & $\begin{array}{l}\text { Tingkat transphobia, } \\
\text { dukungan sosial dan } \\
\text { permasalahan } \\
\text { interpersonal memiliki } \\
\text { hubungan signifikan } \\
\text { dengan depresi. }\end{array}$ & $\begin{array}{l}\text { Konsep diri transgender yang } \\
\text { ditunjukkan dengan skor RSE, } \\
\text { memiliki signifikansi dengan } \\
\text { dengan tingkat depresi pada } \\
\text { transgender }[\mathrm{B}=-, 118 ; \mathrm{p}=, 000] \text {. }\end{array}$ \\
\hline $\begin{array}{l}\text { Minority stress } \\
\text { factors associated } \\
\text { with depression } \\
\text { and anxiety among } \\
\text { transgender and } \\
\text { gender- } \\
\text { nonconforming } \\
\text { youth } \\
\text { (Chodzen et al., } \\
\text { 2019) }\end{array}$ & $\begin{array}{l}\text { Peningkatan skor } \\
\text { appearance congruence } \\
\text { (AC) dapat mencakup } \\
\text { perubahan karakteristik } \\
\text { anatomi/fenotipikal yang } \\
\text { dihasilkan dari intervensi } \\
\text { medis yang menguatkan } \\
\text { gender, termasuk } \\
\text { penekanan pubertas, } \\
\text { terapi hormon, atau } \\
\text { operasi. }\end{array}$ & $\begin{array}{l}\text { Transgender dengan } \\
\text { transfobia tingkat } \\
\text { tinggi \& tingkat } \\
\text { kesesuaian penampilan } \\
\text { identitas gender yang } \\
\text { rendah secara } \\
\text { signifikan lebih } \\
\text { mungkin memenuhi } \\
\text { kriteria diagnostik } \\
\text { untuk kecemasan dan } \\
\text { depresi }\end{array}$ & $\begin{array}{l}\text { Transgender dengan tingkat } \\
\text { Appearance Congruence (AC) } \\
\text { lebih tinggi serta tingkat } \\
\text { Internalized Transphobia (IT) } \\
\text { yang lebih rendah memiliki } \\
\text { tingkat depresi yang lebih } \\
\text { rendah, degan kemungkinan } \\
\text { lebih kecil mengalami gejala } \\
\text { diagnostik depresi. }\end{array}$ \\
\hline $\begin{array}{l}\text { Mental health and } \\
\text { proximal stressors } \\
\text { in transgender men } \\
\text { and women } \\
\text { (Fernández-Rouco } \\
\text { et al., 2019) }\end{array}$ & $\begin{array}{l}\text { Faktor prediktor yang } \\
\text { berpengaruh terhadap } \\
\text { konsep diri transgender } \\
\text { diantaranya harga diri, } \\
\text { citra tubuh, kemampuan } \\
\text { koping, kesepian sosial } \\
\text { dan emosional, dan } \\
\text { kepuasan seksual. }\end{array}$ & $\begin{array}{l}\text { Skor kesepian sosial } \\
\text { tinggi, kemampuan } \\
\text { koping yang rendah, } \\
\text { dan citra tubuh yang } \\
\text { buruk dikaitkan } \\
\text { dengan tingkat depresi } \\
\text { yang lebih tinggi }\end{array}$ & $\begin{array}{l}\text { Uji korelasi terhadap masing- } \\
\text { masing prediktor (strategi } \\
\text { koping aktif, strategi dukungan } \\
\text { sosial dan romantic loneliness), } \\
\text { dihasilkan model korelasi yang } \\
\text { signifikan antara konsep diri } \\
\text { dengan tingkat depresi (F ( } 1 \text {, } \\
116)=12,15, \mathrm{p}<0,001) \text {. }\end{array}$ \\
\hline
\end{tabular}

\section{PEMBAHASAN}

Konsep diri transgender dikategorikan dalam beberapa aspek penilaian diantaranya aspek personal, sosial, dan ideal. Konsep diri transgender dikaitkan dengan tingkat depresi yang dialami oleh transgender. Kondisi tersebut umumnya dialami akibat adanya diskriminasi serta penolakan oleh masyarakat serta kurangnya dukungan sosial baik oleh orang tua, keluarga, dan orang-orang di sekitarnya (Pieter \& Lubis, 2010).
Pembentukan konsep diri pada transgender didasari pula oleh adanya stigma internal atau sikap penerimaan transgender terhadap pandangan negatif masyarakat. Eksplorasi adanya stigma internal berhubungan dengan kejelasan konsep diri (stabilitas dan konsistensi konsep diri), yang dikorelasikan pula dengan tingkat depresi pada transgender. Stigma internal memberikan pengaruh terhadap kejelasan konsep diri (stabilitas dan konsistensi konsep diri), serta berkorelasi dengan tingkat depresi pada transgender. Sejalan dengan penelitian 
tersebut, pengukuran konsep diri diukur pula berdasarkan subskala kongruensi penampilan tubuh (appearance congruence). transgender dengan appearance congruence (AC) lebih tinggi memiliki kemungkinan 2,25 kali lebih kecil mengalami depresi (Chodzen et al., 2019).

Konsep diri pada transgender erat kaitannya pula dengan kepuasan citra tubuh. Klemmer et al. (2018) meneliti bahwa lebih dari $20 \%$ transgender melaporkan kepuasan tubuh rendah dengan nilai kepuasan tubuh rata-rata sebesar 2,87 $(\mathrm{SD}=0,80)$. Rendahnya konsep diri pada transgender ini dikorelasikan dengan status kesehatan mental para transgender terkait tingkat kecemasan dan depresi yang dialaminya. Sebanyak $57,5 \%$ responden terdiagnosa depresi, serta $42,1 \%$ terdiagnosa kecemasan. Penelitian membuktikan pengaruh pemberian terapi hormon dan pembedahan terhadap peningkatan kepuasan citra tubuh yang dikorelasikan dengan pengurangan tingkat depresi pada transgender. Penggunaan hormon seumur hidup berkorelasi dengan tingkat kepuasan tubuh yang lebih tinggi ( $b$ $=0,368, \mathrm{t}=3,29, \mathrm{p}=0,001)$. Kepuasan citra tubuh secara signifikan terkait dengan diagnosis depresi yang dilaporkan $(\mathrm{b}=$ $0,495, \mathrm{p}=0,021$, rasio odds $[\mathrm{OR}]=0,61$ )

Hasil penelitian membuktikan efek signifikan pada frekuensi keinginan bunuh diri dalam dua minggu terakhir diantara para transgender yang telah menjalani kedua operasi dengan transgender yang tidak menjalani TRMI $[\mathrm{B}=-0.2565,95 \%$ BC (CI) -0.7117 to -0.0027 ] (Tucker et al., 2018). Penelitian lain dengan pengambilan sampel lebih besar sebanyak 913 transgender, memprediksi depresi pada transgender dengan faktor kepuasan citra tubuh menggunakan terapi cross-sex hormone treatment (CHT) dibandingkan dengan transgender yang tidak menggunakannya (Witcomb et al., 2018). Temuan ini memiliki kesamaan hasil dengan penelitian sebelumnya yang membuktikan bahwa dilakukannya pembedahan kelamin dan terapi hormon secara signifikan dapat meningkatkan konsep diri transgender terkait aspek citra tubuh, identitas, dan ideal diri, sehingga memberikan pengaruh terhadap penurunan gejala depresi.

Tingkat depresi pada transgender dipengaruhi oleh beberapa faktor prediktor diantaranya harga diri, citra tubuh, kemampuan koping, kesepian sosial dan emosional, dan kepuasan seksual. Melalui analisis regresi dihasilkan model korelasi yang signifikan $(\mathrm{F}(1,116)=12,15, \mathrm{p}$ $<0,001)$. Model ini menyumbang 53\% dari varian depresi. Dalam penelitian ini dilakukan pula uji korelasi terhadap masing-masing prediktor (yaitu, strategi koping aktif, strategi dukungan sosial dan romantic loneliness), dan dihasilkan bahwa skor yang lebih tinggi dalam kesepian sosial, strategi koping, dan citra tubuh yang buruk dikaitkan dengan tingkat depresi yang lebih tinggi (Fernández-Rouco et al., 2019). Model regresi logistik akhir menunjukkan bahwa beberapa variabel prediktor seperti halnya pengangguran, serta riwayat pelecehan fisik atau seksual masa kanak-kanak, menjadi faktor risiko independen yang kuat untuk depresi pada transgender (Rotondi et al., 2011). Beberapa penelitian melalui analisa bivariat membuktikan bahwa peningkatan dukungan identitas, serta keterlibatan dalam organisasi masyarakat dikaitkan dengan berkurangnya kemungkinan transgender 
untuk mengalami gejala yang konsisten dengan depresi, namun bukti terkait pengaruh keterlibatan organisasi terhadap pembentukan konsep diri pada transgender ini masih sangat lemah.

Keterlibatan beberapa peneliti dalam menegakkan bukti terkait korelasi konsep diri dengan depresi pada transgender, menghasilkan beberapa hasil diantaranya: 1) identitas dan citra tubuh menjadi faktor utama konsep diri berkaitan dengan kepuasan terkait identitas gender dan penampilan fisik, yang memiliki korelasi signifikan terhadap tingkat depresi pada transgender; 2) peran dan harga diri transgender berhubungan dengan dukungan sosial yang diterima, menjadi faktor pembentuk konsep diri sosial yang berkorelasi dengan adanya tekanan dan faktor lingkungan penyebab terjadinya depresi; 3) ideal diri merupakan kondisi ideal yang diharapkan secara personal maupun interpersonal, berkaitan dengan aktualisasi diri transgender yang menjadi faktor prediktor, serta berkorelasi dengan strategi koping transgender dalam mengatasi depresi yang dialaminya.

\section{KESIMPULAN DAN SARAN}

Transgender memiliki risiko besar terhadap gejala depresi akibat berbagai tekanan psikologis, baik dari diri sendiri maupun lingkungan di sekitarnya. Tingginya tingkat depresi pada transgender dipengaruhi oleh beberapa faktor diantaranya: kurangnya dukungan sosial, rendahnya harga diri, ketidakpuasan citra tubuh, kurangnya kemampuan koping, kesepian sosial dan emosional, dan rendahnya kepuasan seksual. Berbagai penelitian membuktikan adanya hubungan antara kelima komponen konsep diri (identitas, citra tubuh, peran, harga diri, dan ideal diri) dengan depresi pada transgender. Model regresi logistik melalui analisa bivariat membuktikan bahwa keterlibatan transgender dalam organisasi dikaitkan dengan berkurangnya risiko depresi pada transgender. Belum ada bukti kuat terkait pengaruh keterlibatan dalam organisasi terhadap pembentukan konsep diri pada transgender, sehingga diperlukan adanya penelitian lebih lanjut melalui pengambilan sampel pada kelompok transgender dalam komunitas.

\section{DAFTAR PUSTAKA}

American Psychiatric Association (2013). Diagnostic and statistical manual of mental disorders. (5th Ed.) American Psychiatric Publishing.

Arfanda, F., \& Anwar, S. (2015). Konstruksi sosial masyarakat terhadap waria. Jurnal Ilmu Sosial dan Ilmu Politik Universitas Hasanuddin, 1(1), 93-102.

Budge, S. L., Andelson, J. L., \& Howard, K. A. S. (2013). Anxiety and Depression in transgender individuals: the roles of transition status, loss, social support, and coping. Journal of Consulting and Clinical Psychology, 81(3), 545557. doi: $10.1037 / \mathrm{a} 0031774$

Chodzen, G., Hidalgo, M. A., Chen, D., \& Garofalo, R. (2019). Minority stress factors associated with depression and anxiety among transgender and gender-nonconforming youth. Journal of Adolescent Health, 64(4), 467-471. doi: 10.1016/j.jadohealth.2018.07.006

Fernández-Rouco, N., Carcedo, R., López, F., \& Orgaz, M. (2019). Mental health and proximal stressors in 
transgender men and women. Journal of Clinical Medicine, 8(3), 413. doi: $10.3390 / \mathrm{jcm} 8030413$

Jefferson, K., Neilands, T. B., \& Sevelius, J. (2013). Transgender women of color: Discrimination and Depression symptoms. Ethnicity and Inequalities in Health and Social Care, 6(4), 121-136. doi: 10.1108/EIHSC-08-2013-0013

Kementerian Kesehatan Republik Indonesia. (2018). Hasil Utama Riskesdas. Diperoleh dari http://www.depkes.go.id/resources/ download/infoterkini/materi_rakorp op_2018/Hasil\%20Riskesdas\%202 018.pdfSosial.

Klemmer, C. L., Arayasirikul, S., \& Raymond, H. F. (2018).

Transphobia-based violence, depression, and anxiety in transgender women: The role of body satisfaction. Journal of Interpersonal Violence, 1-23. doi: $10.1177 / 0886260518760015$

Oswald, S. B., \& Lederer, A. M. (2017).

Beyond depression and suicide: The mental health of transgender college students. Social Sciences, 6(7), 1-10. doi: $/ 10.3390 /$ socsci6010020

Pieter, H., \& Lubis, N. (2010). Pengantar psikologi dalam keperawatan. Jakarta: Kencana.

Praptoraharjo, I., \& Navendorff, L. (2015). Quality of life transgender people in Indonesia. Pusat penelitian HIV dan AIDS. Unika Atma Jaya. Diperoleh dari http://arc-atmajaya.org/wpcontent/uploads/2016/08/LaporanPenelitian-SURVEI-KUALITASHIDUP-WARIA.pdf

Reyes, M. E., Alcantara, A. R., Reyes, A.
C., Yulo, P. A., \& Santos, C. I. (2016). Exploring the link between internalized stigma and self-concept clarity among Filipino Transgenders. North American Journal of Psychology, 18(2), 335.

Reyes, M. E. S., Davis, R. D., Yapcengco, F. L., Christine, M. M., Gesmundo, S. C., \& Tores, J. K. M. (2020). Perceived parental acceptance, transgender congruence, and psychological well-Being of Filipino Transgender individuals. North American Journal of Psychology, 22(1), 135-152.

Rotondi, N., Bauer, G., Travers, R., Travers, A., Scanlon, K., \& Kaay, M. (2011). Depression in male-tofemale transgender ontarians: Results from the trans PULSE project. Canadian Journal of Community Mental Health. 30(2), 113-133. doi: 10.7870/cjcmh-20110020

Sarokhani, D., Delpishes, A., Veisani, Y., Sarokhani, M., Manesh, R., \& Sayehmiri, K. (2013). Prevalence of depression among university students: A systematic review and meta analysis study. Depression Research and Treatment 1-7. doi: $10.1155 / 2013 / 373857$

Tantirattanakulchai, P., Hounnaklang, N., \& Kanchanakhan, N. (2019). A cross-sectional research on factors associated with depression among transgender women in Bangkok, Thailand. International Journal of Innovative Technology and Exploring Engineering (IJITEE), VIII(9S2), 2278-3075.

Tucker, R. P., Testa, R. J., Simpson, T. L., Shipherd, J. C., Blosnich, J. R., \& Lehavot, K. (2018). Hormone therapy, gender affirmation surgery, 
and their association with recent suicidal ideation and depression symptoms in transgender veterans. Psychological Medicine. 48(14), 2329-2336.

doi:

$10.1017 / \mathrm{S} 0033291717003853$

Witcomb, G. L., Bouman, W. P., Claes, L., Brewin, N., Crawford, J. R., \& Arcelus, J. (2018). Levels of depression in transgender people and its predictors: Results of a Large matched control study with transgender people accessing clinical services. Journal of Affective Disorders. 235(January). 308-315.

doi: 10.1016/j.jad.2018.02.051

Yusuf, A., Fitryasari R., \& Nihayati, H. E. (2015). Buku ajar keperawatan kesehatan jiwa. Jakarta: Salemba Medika. 